\title{
Editorial
}

\section{Que venha o tornado!}

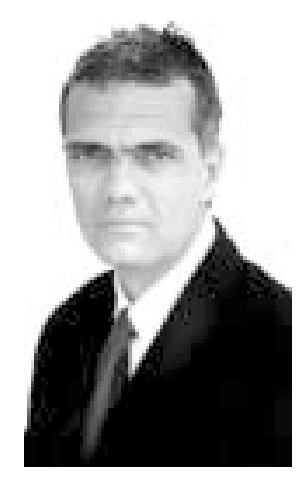

Prof. Dr. Marco Antonio Guimarães da Silva marco@atlanticaedu.com.br

Quase todos nos lembramos do Mágico $\mathrm{Oz}$ (filme de Victor Fleming, EUA, 1939). Os seus 65 anos de existência não o envelheceram. Pelo contrário, ainda nos permitem, neste problemático mundo terceiro milenista, ter o desejo de sermos apanhados por um tornado e transportados para uma terra, "além do arco íris", onde os nossos desejos, ao menos de um emprego digno e decente, pudessem ser realizados.

Para os que não viram o filme, o que move os seus personagens, em busca do mágico de $\mathrm{O} z$, é a busca de alguma solução para os desejos e carências de cada um deles. Ao final da história, todos descobrem que já possuíam dentro de si mesmos aquilo que procuravam do lado de fora. Não precisavam de nenhuma mágica.

O primeiro passo que nos aproxima do filme parece já ter sido dado pela mãe natureza, que, providencialmente, se encarregou de trazer para estes tristes trópicos o Catarina, nosso primeiro furacão. Mas e os demais passos? Considerando que não somos a Dorothy, que não temos o cachorro Totó nem a bruxa boa (Glenda) e tampouco o mágico, parece que também teremos que descobrir, por nós mesmos, que temos o que precisamos para alcançar os nossos objetivos.

Ter que o precisamos precisa ser lido aqui como esforçamo-nos, durante o curso de graduação e pósgraduação, para a divulgação acadêmica do nosso nome, através de publicações e participações em eventos científicos, e, principalmente, descobrirmos a nossa parcela de criatividade.

Voltando ao Mágico de Oz, há uma passagem em que a Dorothy, dando-se conta de que necessitava chegar a cidade Esmeralda, pergunta a Glenda: "Mas por onde inicio?" "Quase todo mundo começa pelo principio, querida", responde Glenda.

É preciso estabelecer um começo. Cada um traçará o seu próprio inicio. Mas gostaria de trazer uma experiência pessoal que já tenho levado para os meus alunos de
Mestrado, Doutorado e, principalmente, para aqueles que fazem os cursos de especialização que estão sob a nossa responsabilidade.

No final dos anos 70, voltando de uma viagem à Europa, buscava uma solução econômica que me permitisse viajar mais. Eram anos difíceis para os professores de Universidades Federais, (ainda hoje o são) que não podiam pensar em viagens intercontinentais. Foi então que, na tentativa de equacionar o problema, enviei, para algumas universidades da Espanha e Portugal, um programa de um curso de biomecânica, que já vinha ministrando no Brasil e em paises da América do Sul, propondo a realização destes cursos naquelas instituições. Para espanto de alguns colegas que me disseram à época que eu não conseguiria porque ninguém me conhecia, em apenas dois meses, já estava de malas prontas. A partir daí, foram mais de 30 cursos ministrados nestes dois paises.

Mais tarde, nos anos 80, com o desejo de propor e fazer trabalho em empresas, procurei, nas páginas amarelas, alguma instituição que pudesse dar respaldo ao trabalho pretendido e ali encontrei a Associação Brasileira de Prevenção de Acidentes (ABPA). Daí por diante, foram mais de 300 palestras e cursos em empresas do grupo e um livro editado sobre prevenção de dor nas costas.

Estes dois exemplos podem ilustrar que o inicio de tudo está em nós mesmos e que não podemos nos ater a "meios convencionais" na busca do nosso tão sonhado emprego. Que venha o tornado!
* Editor científico de Fisioterapia Brasil Pós Doutorado na UFRJ Professor de mestrado recomendado pela CAPES 